\title{
Iron oxidation kinetics and phosphate immobilization along the flow-path from groundwater into surface water
}

\author{
B. van der Grift ${ }^{1,2}$, J. C. Rozemeijer ${ }^{2}$, J. Griffioen ${ }^{1,2}$, and Y. van der Velde ${ }^{3}$ \\ ${ }^{1}$ Department of Innovation, Environmental and Energy Sciences - Faculty of Geosciences, Utrecht University, \\ P.O. Box 80115,3508 TA Utrecht, the Netherlands \\ ${ }^{2}$ Deltares, P.O. Box 85467, 3508 AL Utrecht, the Netherlands \\ ${ }^{3}$ Soil Geography and Landscape, Wageningen University and Research Centre, Droevendaalsesteeg 4, \\ 6708 PB Wageningen, the Netherlands \\ Correspondence to: B. van der Grift (bas.vandergrift@ deltares.nl)
}

Received: 20 May 2014 - Published in Hydrol. Earth Syst. Sci. Discuss.: 23 June 2014

Revised: 30 September 2014 - Accepted: 17 October 2014 - Published: 27 November 2014

\begin{abstract}
The retention of phosphorus in surface waters through co-precipitation of phosphate with Feoxyhydroxides during exfiltration of anaerobic Fe(II) rich groundwater is not well understood. We developed an experimental field set-up to study $\mathrm{Fe}(\mathrm{II})$ oxidation and $\mathrm{P}$ immobilization along the flow-path from groundwater into surface water in an agricultural experimental catchment of a small lowland river. We physically separated tube drain effluent from groundwater discharge before it entered a ditch in an agricultural field. Through continuous discharge measurements and weekly water quality sampling of groundwater, tube drain water, exfiltrated groundwater, and surface water, we investigated Fe(II) oxidation kinetics and $\mathrm{P}$ immobilization processes. The oxidation rate inferred from our field measurements closely agreed with the general rate law for abiotic oxidation of $\mathrm{Fe}(\mathrm{II})$ by $\mathrm{O}_{2}$. Seasonal changes in climatic conditions affected the $\mathrm{Fe}$ (II) oxidation process. Lower $\mathrm{pH}$ and lower temperatures in winter (compared to summer) resulted in low $\mathrm{Fe}$ oxidation rates. After exfiltration to the surface water, it took a couple of days to more than a week before complete oxidation of $\mathrm{Fe}(\mathrm{II})$ is reached. In summer time, Fe oxidation rates were much higher. The Fe concentrations in the exfiltrated groundwater were low, indicating that dissolved $\mathrm{Fe}(\mathrm{II})$ is completely oxidized prior to inflow into a ditch. While the $\mathrm{Fe}$ oxidation rates reduce drastically from summer to winter, $\mathrm{P}$ concentrations remained high in the groundwater and an order of magnitude lower in the surface water throughout the year. This study shows very fast immobilization of dissolved $\mathrm{P}$ during the initial
\end{abstract}

stage of the $\mathrm{Fe}(\mathrm{II})$ oxidation process which results in $\mathrm{P}$ depleted water before Fe(II) is completely depleted. This cannot be explained by surface complexation of phosphate to freshly formed $\mathrm{Fe}$-oxyhydroxides but indicates the formation of Fe(III)-phosphate precipitates. The formation of Fe(III)phosphates at redox gradients seems an important geochemical mechanism in the transformation of dissolved phosphate to structural phosphate and, therefore, a major control on the $P$ retention in natural waters that drain anaerobic aquifers.

\section{Introduction}

Eutrophication of freshwater ecosystems following high nutrient loads is a widely recognized water quality problem in agricultural catchments. Phosphorus (P) is often a limiting nutrient in wetlands or fresh aquatic ecosystems (Elser et al., 2007; Wassen et al., 2005) and therefore a key parameter in controlling eutrophication. $\mathrm{P}$ enters surface waters through point-sources such as waste water treatment plants and nonpoint sources via surface runoff and exfiltration of soil water and groundwater. Especially, the fate of $\mathrm{P}$ in surface waters originating from non-point sources is controlled strongly by biogeochemical nutrient cycling processes at the soil-water interface (Dahm et al., 1998; Reddy et al., 1999; Dunne et al., 2006).

To date, research and policy on $\mathrm{P}$ pollution from non-point sources have focused almost entirely on transfer of particulate phosphate from agricultural land to surface waters via 
overland flow or other fast flow paths during storm flow events (Withers and Haygarth, 2007; Sharpley et al., 2008; Jordan et al., 2012). However, several studies in fresh water systems suggested that substantial dissolved-phosphate loads in surface waters may originate from exfiltration of shallow or deep groundwater (Holman et al., 2008; Dahlke et al., 2012; Scanlon et al., 2005). This is especially likely to occur in delta areas (Griffioen, 2006; Hayashi and Yanagi, 2009), where the soil water and shallow groundwater is typically $\mathrm{pH}$-neutral to slightly acid, anoxic, and iron-rich. The anoxic conditions are very suitable to dissolve phosphate in groundwater, which may result in relative high concentrations of dissolved phosphate from natural origin (Griffioen et al., 2013) or from leached manure or fertilizers (Chardon et al., 2007). In contrast, the chemical composition of surface waters in delta areas is normally $\mathrm{pH}$-neutral to slightly alkaline and oxic with low dissolved iron and phosphate concentrations. This difference in chemical composition between groundwater and surface water creates strong redox and $\mathrm{pH}$ gradients at the groundwater-surface water interface (Frei et al., 2012; Carlyle and Hill, 2001). At this interface, the oxidation of iron(II) followed by iron(III) hydrolysis and precipitation of iron oxyhydroxides is the dominant chemical reaction (Griffioen, 2006; Gunnars et al., 2002; Kaegi et al., 2010; von Gunten and Schneider, 1991; Baken et al., 2013), that determines the fate of many biochemically important solutes that co-precipitate with the iron oxyhydroxides such as $\mathrm{PO}_{4}$ (Châtellier et al., 2004; Deppe and Benndorf, 2002; Fox, 1989; Lienemann et al., 1999; Mayer and Jarrell, 2000; Voegelin et al., 2013) and $\mathrm{AsO}_{4}$ (Meng et al., 2002; Roberts et al., 2004; Hug and Leupin, 2003).

The majority of studies on redox processes and $\mathrm{P}$ dynamics at the groundwater-surface water interface focus on mobilization of phosphate by reductive dissolution of Fe oxyhydroxides in riparian zones or wetlands in response to rewetting (Macrae et al., 2011; Maassen and Balla, 2010; Shenker et al., 2005). In contrast, relatively little is known about the oxidation of $\mathrm{Fe}$ (II) in the transition zone from groundwater into surface water in lowland delta areas with (periodic) exfiltration of anaerobic groundwater in relation to $P$ retention in surface water. The rate of $\mathrm{Fe}$ (II) oxidation strongly depends on $\mathrm{pH}$. At neutral $\mathrm{pH}$, it is a fast reaction that is expected to occur within hours when molecular oxygen is not limited (Stumm and Lee, 1961). At pH values around 6, it may take a couple of days before complete abiotic oxidation of Fe(II) occurs. The reaction rate also depends on oxygen concentration and temperature. Spiteri et al. (2006) investigated the effect of $\mathrm{O}_{2}$ and $\mathrm{pH}$ gradients on oxidative precipitation of $\mathrm{Fe}$ (II) and subsequent phosphate sorption along a flow-line in a subterranean estuary where groundwater discharges to the sea. Their results showed that the $\mathrm{pH}$ is a more controlling factor that the $\mathrm{O}_{2}$ concentration.

To our knowledge there are no field studies on the mechanisms and rates of iron oxidation with associated binding of phosphate in lowland catchments that drain anaerobic groundwater while these processes may have an important control on mobility of $\mathrm{P}$ in surface water (Baken et al., 2013; Griffioen, 2006; Fox, 1989). Moreover, as most of the work on $\mathrm{Fe}$ (II) oxidation and incorporation of phosphate into $\mathrm{Fe}(\mathrm{III})$ precipitates is performed on synthetic media, the kinetics of these processes in the natural environment are poorly known. A better understanding of these processes will improve our knowledge of P retention mechanisms in surface waters with exfiltration of anaerobic groundwater as driving force.

To study the dynamics in $\mathrm{Fe}(\mathrm{II})$ oxidation and $\mathrm{P}$ immobilization along the flow-path from groundwater into surface water, we developed an experimental field set-up in an agricultural catchment of a small lowland river (the Hupsel Brook). Previous studies in the Hupsel Brook catchment have demonstrated that the groundwater in the catchment is predominantly anoxic and contains relatively high dissolved $\mathrm{P}$ concentrations in a range of 0.3 to $1.0 \mathrm{mg} \mathrm{L}^{-1}$ (Rozemeijer et al., 2010a). At the catchment outlet particulate $P$ is, however, the major contributor to the total $\mathrm{P}$ concentrations in the surface water (Rozemeijer et al., 2010b). This indicates that transformation from dissolved $\mathrm{P}$ in the groundwater to particulate $\mathrm{P}$ in the surface water must have occurred.

In this study we aim (1) to measure the dynamics of $\mathrm{Fe}(\mathrm{II})$ and phosphate concentrations along the flow-path from groundwater into surface water in a typical lowland catchment in the Netherlands (2) to infer reaction rates and mechanisms that influence the iron oxidation process by a combination of data analysis and chemical modelling and (3) to explore the phosphate immobilization process during the flow of anaerobic iron-rich groundwater towards surface water.

\section{Methods}

\subsection{Study area}

An experimental set-up was installed in the Hupsel Brook agricultural lowland catchment, The Netherlands (Fig. 1) $\left(52^{\circ} 03^{\prime} \mathrm{N} ; 6^{\circ} 38^{\prime} \mathrm{E}\right)$. The size of this catchment is $6.64 \mathrm{~km}^{2}$, with altitudes ranging from 22 to $36 \mathrm{~m}$ a.m.s.l. (above mean sea level). A weather station of the Royal Dutch Meteorological Institute (KNMI, De Bilt, the Netherlands) is located within the catchment. The Hupsel Brook catchment has a moderate maritime climate with an average annual temperature of $9.5^{\circ} \mathrm{C}$ and average annual precipitation of $770 \mathrm{~mm}$. Our field-scale experiment location in the Hupsel catchment is a $9000 \mathrm{~m}^{2}$ tube drained meadow dominated by the grass Lolium perenne; surface elevation ranges from 28 to 31 $\mathrm{m}$ a.s.m.l. and a ditch (average depth of $1.2 \mathrm{~m}$ below soil surface) borders the field at the eastern side. This ditch drains a sub-catchment of the Hupsel Brook as indicated in Fig. 1. The direction of the groundwater flow in the field is from northwest to southeast. The groundwater drains towards the 


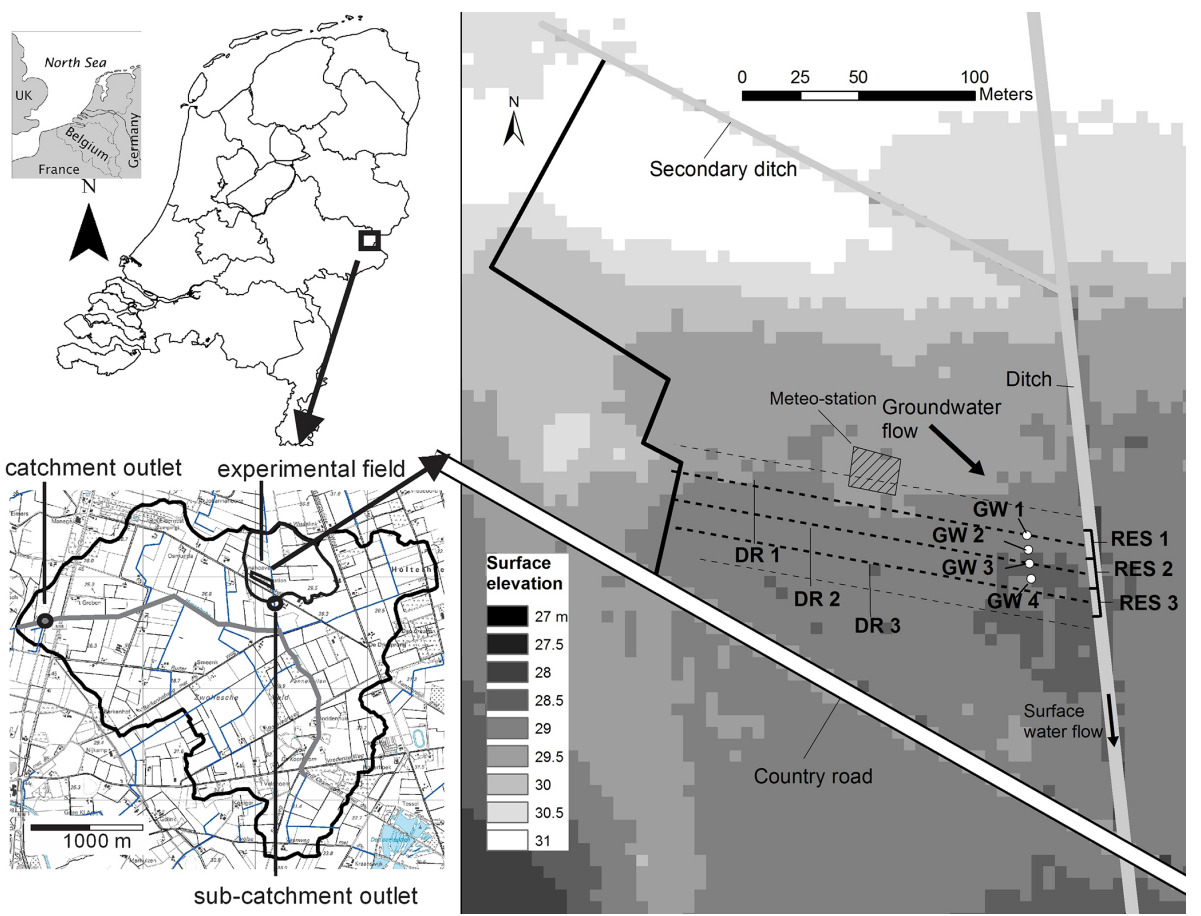

Figure 1. Location of the Hupsel catchment and the experimental field. The catchment map shows the sub-catchment outlet and catchment outlet. The field map shows the three measured tube drains (DR), the four groundwater wells (GW) and the location of the in-stream reservoirs (RES). The direction of the groundwater flow is taken from Rozemeijer et al. (2010c).

eastern ditch or flows into the adjacent field south of the experimental field (Rozemeijer et al., 2010c). The drainage tubes are separated $14.5 \mathrm{~m}$ from each other and discharge into the eastern ditch at $90 \mathrm{~cm}$ depth. To separate the water fluxes of different flow routes towards the eastern ditch, three adjacent sheet pile reservoirs were built in the ditch (Fig. S1 in the Supplement). These in-stream reservoirs were constructed around single drainage outlets and stretched along $43.5 \mathrm{~m}$ of the field. The wooden sheet piles were driven into an impermeable $30 \mathrm{~m}$ thick Miocene clay layer starting at a depth of 3 to $5 \mathrm{~m}$ to capture all groundwater flow from the field into the ditch. The in-stream reservoirs captured overland flow, interflow, direct precipitation and groundwater flow from the thin, phreatic aquifer above the Miocene clay layer. The water levels in the reservoirs were measured continuously with pressure sensors from November 2007 to October 2008. The water levels inside the in-stream reservoirs were maintained at the ditch water level by pumps. Excess water was pumped from the in-stream reservoirs into the ditch, and the pumped volumes were recorded with digital flux metres (Van der Velde et al., 2010). The water flow from the individual tube drains was separated from the other flow routes by connecting each drain to a $500 \mathrm{~L}$ vessel. Water from these vessels was pumped into the ditch and volumes were measured with water flux metres (Van der Velde et al., 2010). The water temperature was measured continuously direct downstream the reservoirs.
Four groundwater wells were installed for sampling of groundwater in a transect across the experimental field parallel to the ditch at a distance of $20 \mathrm{~m}$ from the ditch. The filters of the wells were installed $2-3 \mathrm{~m}$ below the surface. More detailed information about the Hupsel catchment and all installations and measurements is found in Van der Velde et al. (2010).

\subsection{Water quality measurements}

We collected water samples from the four groundwater wells, the three tube drains and the three in-stream reservoirs from May 2007 until December 2008. In addition, surface water samples were taken from the sub-catchment outlet and the catchment outlet. All samples were taken weekly using a peristaltic pump. During the dry summer period (July to October), the tube drains and in-stream reservoirs occasionally ran dry and sampling was sometimes not possible. We reduced the sampling to a biweekly scheme during this period. The samples were filtered in situ $(0.45 \mu \mathrm{m})$ and subsamples for ICP analysis were directly acidified with $\mathrm{HNO}_{3}$. The electrical conductivity and $\mathrm{pH}$ were measured immediately in the field using a flow-through cell. The samples were analysed for metals, nutrients and anions within $48 \mathrm{~h}$ using Ion Chromatography $\left(\mathrm{NO}_{3}, \mathrm{SO}_{4}, \mathrm{Cl}\right)$, ICP-AES ( $\mathrm{Na}, \mathrm{K}, \mathrm{Ca}, \mathrm{Fe}$, $\mathrm{Mg}, \mathrm{Si}$ ), ICP-MS (P, Al) and AA3 (Automated Segmented Flow Analyser) $\left(\mathrm{NH}_{4}\right)$. Alkalinity was measured by titration. We used a variable span smoother based on local linear fits 
(Friedman, 1984) to aggregate trends trough the concentration measurements.

\subsection{Modelling reaction kinetics}

To test the validity of existing chemical models developed under laboratory condition for the oxidation of $\mathrm{Fe}$ and coprecipitation of $\mathrm{PO}_{4}$ for our field situation, we modelled the $\mathrm{Fe}$ and $\mathrm{PO}_{4}$ concentrations in the reservoirs with PHREEQC (Parkhurst and Appelo, 1999) with the WATEQ4F database (Ball and Nordstrom, 1991) using the representative aqueous composition of the groundwater (Table S1 in the Supplement). We compared the range and yearly average trend of measured $\mathrm{Fe}$ concentrations with increasing transit time of the water within the reservoirs with model scenarios. Therefore, we performed model scenarios representing a typical summer situation, a typical winter situation and a yearly average situation with their accompanying rate controlling parameters, as discussed later. First, the Fe oxidation kinetics in the reservoirs were described as a first-order reaction process following the general rate law for chemical oxidation of $\mathrm{Fe}(\mathrm{II})$ by $\mathrm{O}_{2}$ :

$-\frac{\mathrm{dFe}(\mathrm{II})}{\mathrm{d} t}=k[\mathrm{Fe}(\mathrm{II})]\left[\mathrm{OH}^{-}\right]^{2} P_{\mathrm{O}_{2}}$

with a value for the abiotic rate constant $k$ at $20^{\circ} \mathrm{C}$ of 7.9 $( \pm 2.47) \times 10^{13} \mathrm{M}^{-2} \mathrm{~atm}^{-1} \mathrm{~min}^{-1}$ (Stumm and Lee, 1961). Now by assuming a continuous stirred tank reactor (CSTR) with perfect mixing and steady-state concentrations, we can describe $\mathrm{Fe}$ (II) concentrations in the reservoir as function of mean transit times of water through the reservoirs (Perry et al., 1997):

$\mathrm{Fe}_{\mathrm{r}}=\frac{\mathrm{Fe}_{i}}{1+\left(k^{\prime} \cdot \bar{T}\right)}$,

where $\mathrm{Fe}_{\mathrm{r}}$ is the $\mathrm{Fe}$ (II) concentration of the water in the reservoir, $\mathrm{Fe}_{i}$ is the $\mathrm{Fe}$ (II) concentration of the groundwater that flows into the reservoir, $k^{\prime}$ is the pseudo first-order reaction rate according Eq. (1) $\left(k\left[\mathrm{OH}^{-}\right]^{2} P_{\mathrm{O}_{2}}\right)$ and $\bar{T}$ is the mean transit time.

The mean transit time $\bar{T}$ of the water leaving the reservoirs at time $t$ can be approximated through the assumption of fully mixed reservoirs with a variable flow $(q(t))$ and volume $(V(t))$, following (Botter et al., 2011):

$\bar{T}(t)=\int_{\theta}^{\infty} \frac{q(t-T)}{V(t-T)} e^{-\int_{0}^{T} \frac{q(t-T+\tau)}{V(t-T+\tau)} d \tau} \cdot T \mathrm{~d} T$,

where $q(t-T)$ is the reservoir discharge and $V(t-T)$ is the reservoir volume at time $t$ that has been inside the reservoir (i.e. the transit time) for a period $T$.

In a second step, the uptake of phosphate to Fe precipitates was modelled with two models using different concepts.
First, surface complexation to ferrihydrite was considered using the Dzombak and Morel (1990) model. Surface complexation of carbonate and silicate to ferrihydrite was included, using the stability constants of Van Geen et al. (1994) and Bonte (2013). Second, precipitation of an ideal solid-solution with two endmembers, amorphous $\mathrm{Fe}$ hydroxide $\left(\mathrm{Fe}(\mathrm{OH})_{3}\right)$ and strengite $\left(\mathrm{FePO}_{4} \cdot 2 \mathrm{H}_{2} \mathrm{O}\right.$ ), was considered (Fox, 1989; Griffioen, 2006). The formation of the solid-solution during the oxidation of $\mathrm{Fe}$ (II) was modelled using the solubility products of amorphous Fe hydroxide and strengite from the WATEQ4F database. Surface complexation was not included in the solid-solution model.

\section{Results}

\subsection{Fe concentrations}

The groundwater samples (Fig. 2a) had Fe concentrations ranging between 0.2 and $45.5 \mathrm{mg} \mathrm{L}^{-1}$ with an average of $15.9 \mathrm{mg} \mathrm{L}^{-1}$ and a median value of $14.5 \mathrm{mg} \mathrm{L}^{-1}$. The groundwater showed a temporal and spatial variation in $\mathrm{Fe}$ concentrations, but they were generally higher than in the other water types. The $\mathrm{NO}_{3}-\mathrm{N}$ concentrations of the groundwater were commonly low with an average of $0.20 \mathrm{mg} \mathrm{L}^{-1}$ and a median value of $0.045 \mathrm{mg} \mathrm{L}^{-1}$. The redox status of the groundwater can, therefore, be assessed as anaerobic and the measured Fe concentration can be attributed to Fe(II). The measured groundwater concentrations are common values for anaerobic groundwater in the eastern part of the Netherlands (Griffioen et al., 2013). The measured Fe concentration at sampling locations other than the groundwater may partly be attributed to dissolved Fe(III) colloids or complexed Fe(II) that penetrates through the $0.45 \mu \mathrm{m}$ filters and dissolve in the acidic media, this is discussed in the next section.

The tube drain water samples (Fig. 2b) had Fe concentrations ranging between 0.4 and $18.9 \mathrm{mg} \mathrm{L}^{-1}$ with an average of $4.5 \mathrm{mg} \mathrm{L}^{-1}$ and a median value of $1.9 \mathrm{mg} \mathrm{L}^{-1}$. The Fe concentrations of tube drains 1 and 2 were for the majority of samples lower than $2 \mathrm{mg} \mathrm{L}^{-1}$. At some moments in the winter months of 2007-2008 tube drain 2 had Fe concentrations around $5 \mathrm{mg} \mathrm{L}^{-1}$. Tube drain 3 showed a large change in $\mathrm{Fe}$ concentration: the $\mathrm{Fe}$ concentrations increased from values around $2 \mathrm{mg} \mathrm{L}^{-1}$ to values between 10 and $15 \mathrm{mg} \mathrm{L}^{-1}$ during the period September 2007-November 2007 and exceeded $15 \mathrm{mg} \mathrm{L}^{-1}$ in November and December 2008. This water approached the Fe concentrations of the groundwater. A change in concentration of redox-sensitive components like $\mathrm{NO}_{3}$, $\mathrm{NH}_{4}, \mathrm{Mn}, \mathrm{As}, \mathrm{HCO}_{3}$ was also observed in the drain 3 water (not shown).

The reservoir water samples (Fig. 2c) had Fe concentrations ranging between 0.1 and $34.6 \mathrm{mg} \mathrm{L}^{-1}$ with an average of $3.9 \mathrm{mg} \mathrm{L}^{-1}$ and a median value of $2.0 \mathrm{mg} \mathrm{L}^{-1}$. There was a winter peak in the $\mathrm{Fe}$ concentration of the in-stream reservoirs. During the winter (November-February), the $\mathrm{Fe}$ 

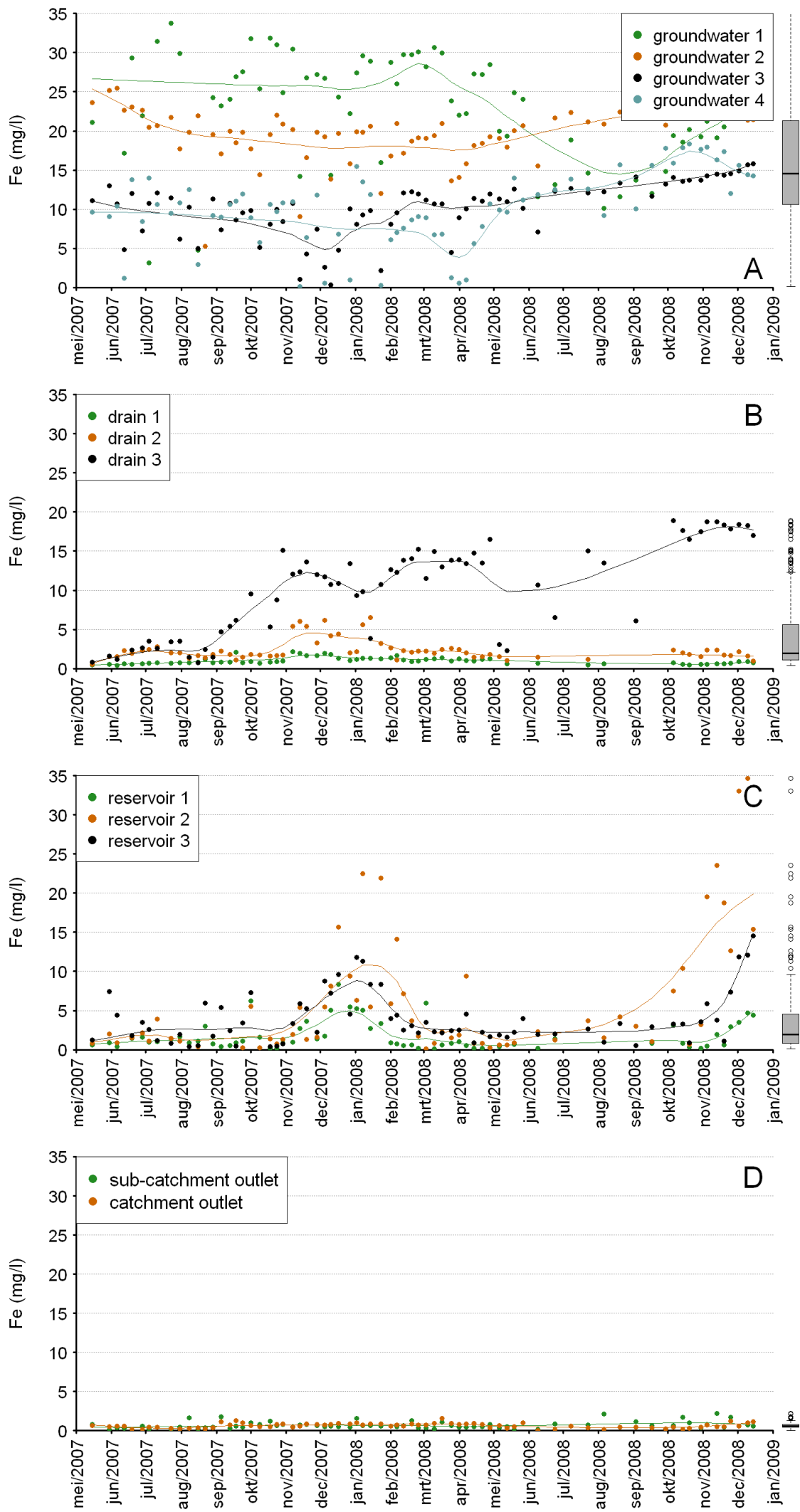

Figure 2. Time series and boxplots of Fe concentration of groundwater (a), tube drain water (b), in-stream reservoir water (c) and surface water (d). The smoothing line through the measured data points is calculated with the method of Friedman (1984). The bold solid line within each box plot is the median concentration. The lower and upper side of the box represents the 0.25 and the 0.75 quantile. Whiskers extend to the maximum and minimum value unless the values are larger then 1.5 times the box length. Open circles are extreme values. 
concentration reached the level of the Fe concentrations of the groundwater $\left(5-35 \mathrm{mg} \mathrm{L}^{-1}\right)$, while in summer season (April-September) a majority of samples had Fe concentrations lower than $5 \mathrm{mg} \mathrm{L}^{-1}$ with an average of $1.76 \mathrm{mg} \mathrm{L}^{-1}$. The range and average of the Fe concentrations differed between the three reservoirs during the winter period (Table 1). Reservoir 2 showed the highest concentrations followed by reservoir 3 and subsequently reservoir 1 . Likely, this was the result of spatial variation of $\mathrm{Fe}$ concentrations in the groundwater, where reservoirs 2 and 3 drained groundwater with higher Fe concentrations than reservoir 1. On average, groundwater wells 1 and 2 had the highest Fe concentrations (Fig. 2a). The groundwater flow in the field is approximately from northwest to southeast (Rozemeijer et al., 2010c). Therefore, it is conceivable that this Fe-rich groundwater flows into reservoirs 2 and 3 (Fig. 1).

The surface water samples (Fig. 2d) had Fe concentrations ranging between 0.15 and $2.21 \mathrm{mg} \mathrm{L}^{-1}$ with an average of $0.68 \mathrm{mg} \mathrm{L}^{-1}$ and a median value of $0.60 \mathrm{mg} \mathrm{L}^{-1}$. There was no seasonal variation and no difference between the subcatchment outlet and catchment outlet.

\subsection{P concentrations}

The dissolved $\mathrm{P}$ concentrations of the groundwater were an order of magnitude higher than that of the tube drain water, reservoir water and surface water (Fig. 3). Where the median $\mathrm{P}$ concentration equalled $0.33 \mathrm{mg} \mathrm{L}^{-1}$ in the groundwater, it was around $0.02 \mathrm{mg} \mathrm{L}^{-1}$ for all other water types. Despite some short-scale temporal variation in the $\mathrm{P}$ concentration at individual groundwater wells, the data showed increased $\mathrm{P}$ concentrations during summer (Fig. 3a) (we did not investigate this further).

There was an increase in $\mathrm{P}$ concentration at tube drain 3 starting in November 2007 (Fig. 3b). This was 2 months after the increase of Fe (Fig. 3b). However, the P concentration at tube drain 3 after the redox transition did not reach the level of the P concentration of anaerobic groundwater (Fig. S3).

There was no clear seasonal trend in $\mathrm{P}$ concentrations in the reservoirs and surface water (Fig. $3 c$ and d). Note that the $\mathrm{Fe}$ concentrations of the reservoir water in winter time almost matched that of the anaerobic groundwater but the $\mathrm{P}$ concentrations were an order of magnitude lower.

\subsection{Supporting variables}

Following Eqs. (1) and (2), Fe concentrations can be explained from, $\mathrm{pH}$, temperature, oxygen pressure of the water and the transit time of water inside the reservoirs. These variables have been measured directly or approximated. There was a seasonal variation in the $\mathrm{pH}$ of the water in the reservoirs (Fig. 4). The $\mathrm{pH}$ varied between 6 and 6.5 with an average of 6.16 during the cold November to March. Although the sampling frequency was lower during the warmer April to October, the majority of samples had $\mathrm{pH}$ values above 6.5
Table 1. Averaged $\mathrm{P}$ and $\mathrm{Fe}$ concentrations and molar $\mathrm{P} / \mathrm{Fe}$ ratios of the groundwater, the reservoir water during winter time and the drain 3 effluent.

\begin{tabular}{lrrr}
\hline & $\begin{array}{r}\text { avg P } \\
\mu \mathrm{mol} \mathrm{L}^{-1}\end{array}$ & $\begin{array}{r}\text { avg Fe } \\
\mu \mathrm{mol} \mathrm{L}\end{array}$ & $\begin{array}{r}\text { avg P/Fe } \\
\text { ratio }\end{array}$ \\
\hline Groundwater 1 & 22.1 & 422 & 0.053 \\
Groundwater 2 & 5.6 & 353 & 0.016 \\
Groundwater 3 & 12.0 & 182 & 0.066 \\
Groundwater 4 & 14.6 & 184 & 0.079 \\
Drain 3 after Sep 2007 & 2.6 & 235 & 0.011 \\
Reservoir 1 Nov-Feb & 0.5 & 56 & 0.009 \\
Reservoir 2 Nov-Feb & 1.0 & 229 & 0.004 \\
Reservoir 3 Nov-Feb & 1.6 & 119 & 0.014 \\
\hline
\end{tabular}

with an average of 6.6. The temperature of the ditch water varied between 2.7 and $21.5^{\circ} \mathrm{C}$ (Fig. 5).

To explore Fe oxidation kinetics and $\mathrm{P}$ immobilization during exfiltration on anaerobic groundwater into surface water we calculated the mean transit time of the exfiltrated groundwater in the reservoirs from the reservoir discharge and the reservoir volume according to Eq. (3). The reservoir discharge, and therefore the groundwater inflow into the reservoirs, showed an decrease from winter to summer (Van der Velde et al., 2010). The reservoir volumes decreased as well but to a lesser extent than the reservoir discharge (Supplement S1). This resulted in an increase of the mean transit time of the water in the reservoirs. The mean transit time varied between 2 and 6 days during the period November 2007-March 2008 (Fig. 5) with longer mean transit times during relatively short, drier periods and mean transit times shorter than 2 days during the intensive discharge peaks. From April 2008 to December 2008 the variation in mean transit time was larger compared to the period November 2007-March 2008. Mean transit times longer than 8 days were common in the period from April 2008 to December 2008. During dry periods the mean transit time increased gradually up to 20 days. Precipitation events following these drier periods reduced the mean transit time immediately to a few days. During five events in the summer of 2008 reservoir 1 went dry and, therefore, no transit time could be calculated.

\section{Discussion}

\subsection{Behaviour of $\mathrm{Fe}$}

The first objective of our study was to measure the dynamics of $\mathrm{Fe}$ concentrations along the flow path from groundwater into surface water. We measured a clear trend in dissolved Fe concentration with concentration in the groundwater and low concentrations in the surface water. The Fe concentrations of the reservoir water and tube drain water were dynamic over the year. The higher Fe concentrations 

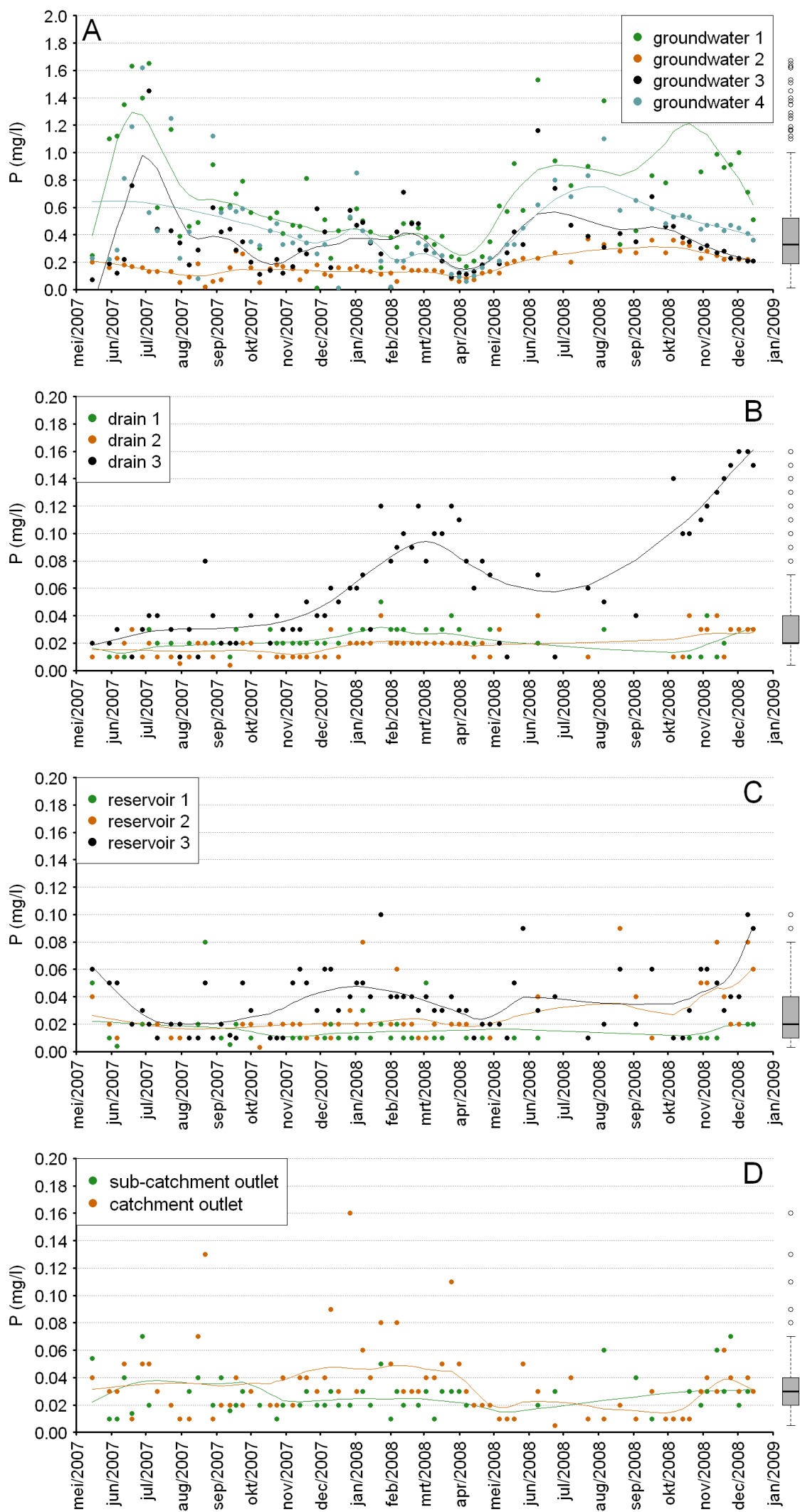

Figure 3. Time series and boxplots of dissolved total $\mathrm{P}$ concentrations of groundwater (a), tube drain water (b), in-stream reservoir water (c) and surface water (d). (b), (c) and (d) share the same $y$-axis. Remarks as for Fig. 2. 


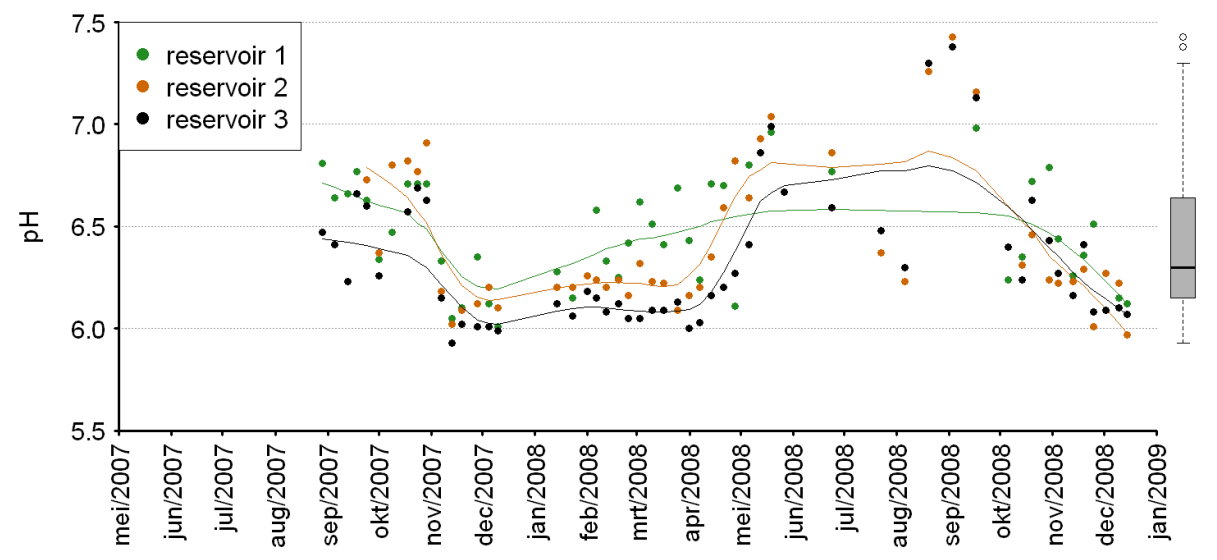

Figure 4. Time series of $\mathrm{pH}$ of reservoir water. Remarks as for Fig. 2.

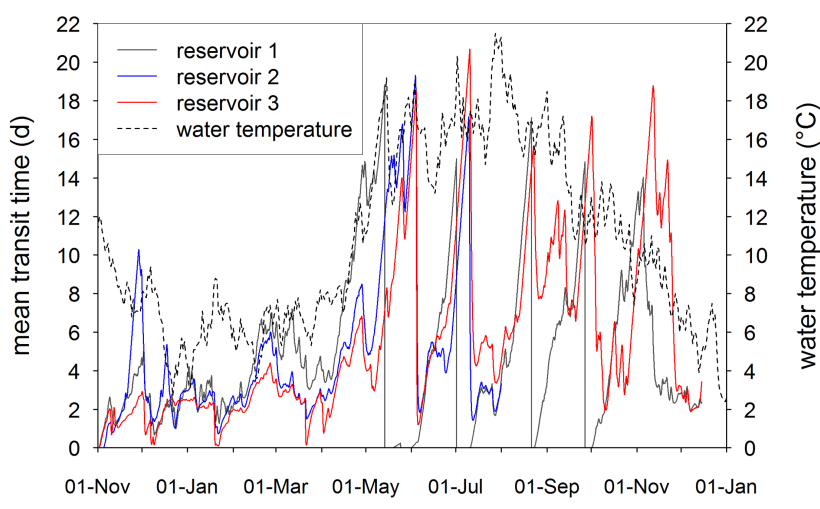

Figure 5. Mean transit time of the water inside the in-stream reservoirs and the temperature of the ditch water directly downstream of the reservoirs.

of the reservoir water during winter time suggest that only a part of the $\mathrm{Fe}(\mathrm{II})$ in the groundwater that was leached into the reservoirs was oxidized at the time of sampling. In summer time, the dissolved Fe concentrations of the water in the reservoirs are low. Not all the dissolved $\mathrm{Fe}$ in the tube drain water, reservoir water and surface water samples can be assumed as Fe(II). The presence of dissolved Fe after $0.45 \mu \mathrm{m}$ filtration in oxygenated water has been variously attributed to $\mathrm{Fe}$ (III) in colloidal phases (Lyvén et al., 2003) or complexed $\mathrm{Fe}(\mathrm{II})$ (Lofts et al., 2008). The particulate colloidal Fe(III) can exist as both organic complex and small hydroxide particle (Lyvén et al., 2003; Allard et al., 2004; Benedetti et al., 2003). Colloidal Fe(III) is stabilized against aggregation by binding of dissolved organic carbon (DOC) on its surface. $\mathrm{Neal}$ et al. (2008) found positive correlations between $\mathrm{Fe}$ and DOC concentrations of river water. However, dissolved $\mathrm{Fe}$ concentration in streams and rivers with near-neutral $\mathrm{pH}$ values do only seldom exceed $0.5 \mathrm{mg} \mathrm{L}^{-1}$ (Salminen, 2005; Neal et al., 2008). The Fe concentration in our drain water and reservoir water samples are commonly much higher and can, therefore, largely be attributed to Fe(II).

\subsubsection{Reservoirs}

The Fe concentrations of the reservoir water depend on the rate of the $\mathrm{Fe}$ oxidation process in combination with the flux of Fe-rich groundwater into the reservoirs and the transit time in the reservoirs. The $\mathrm{pH}$, oxygen concentration and temperature are the major controls on the $\mathrm{Fe}(\mathrm{II})$ oxidation rate. The difference in maximum and minimum temperature of the ditch water is almost $20^{\circ} \mathrm{C}$ (Fig. 5). A tenfold increase of the rate upon raising the temperature by $15^{\circ} \mathrm{C}$ is reported for abiotic oxidation of Fe(II) by oxygen (Sung and Morgan, 1980). This is mainly caused by the change in $\mathrm{OH}^{-}$activity due to the temperature dependence of the ionization constant of water.

There was a seasonal variation in the $\mathrm{pH}$ of the water in the reservoirs (Fig. 4), with lower values in winter and higher values in summer. According to the rate law for abiotic Fe(II) oxidation Eq. (3), a drop of half a $\mathrm{pH}$ unit for $\mathrm{pH}$ around 6-7 results theoretically in a ninefold increase in the half-life time of $\mathrm{Fe}(\mathrm{II})$. Therefore, the seasonal variation in the $\mathrm{pH}$ is another control on the dynamics in the Fe concentration of the reservoirs water. The smaller seasonal variation in the $\mathrm{pH}$ and $\mathrm{Fe}$ concentration in reservoir 1 compared to reservoirs 2 and 3 supports this conclusion.

Seasonal increases in $\mathrm{pH}$ may be induced by $\mathrm{CO}_{2}$ degassing of surface water or by photosynthesis in the surface water column (House and Denison, 1997; Neal et al., 2002). The average $P_{\mathrm{CO}_{2}}$ of all groundwater samples is $0.056 \mathrm{~atm}$, which is a common value for groundwater in the Netherlands (Griffioen et al., 2013). For the reservoir water during the summer months and winter months this is 0.024 and $0.048 \mathrm{~atm}$, respectively. Degassing of $\mathrm{CO}_{2}$ is kinetically controlled and, therefore, it may take a couple of days before equilibrium with air is reached. Obviously, photosynthesis occurs mainly during summer months. So, we assume that longer transit times and higher temperatures of the water in the reservoirs during summer months compared to the winter months resulted in more extensive $\mathrm{CO}_{2}$ degassing. This 

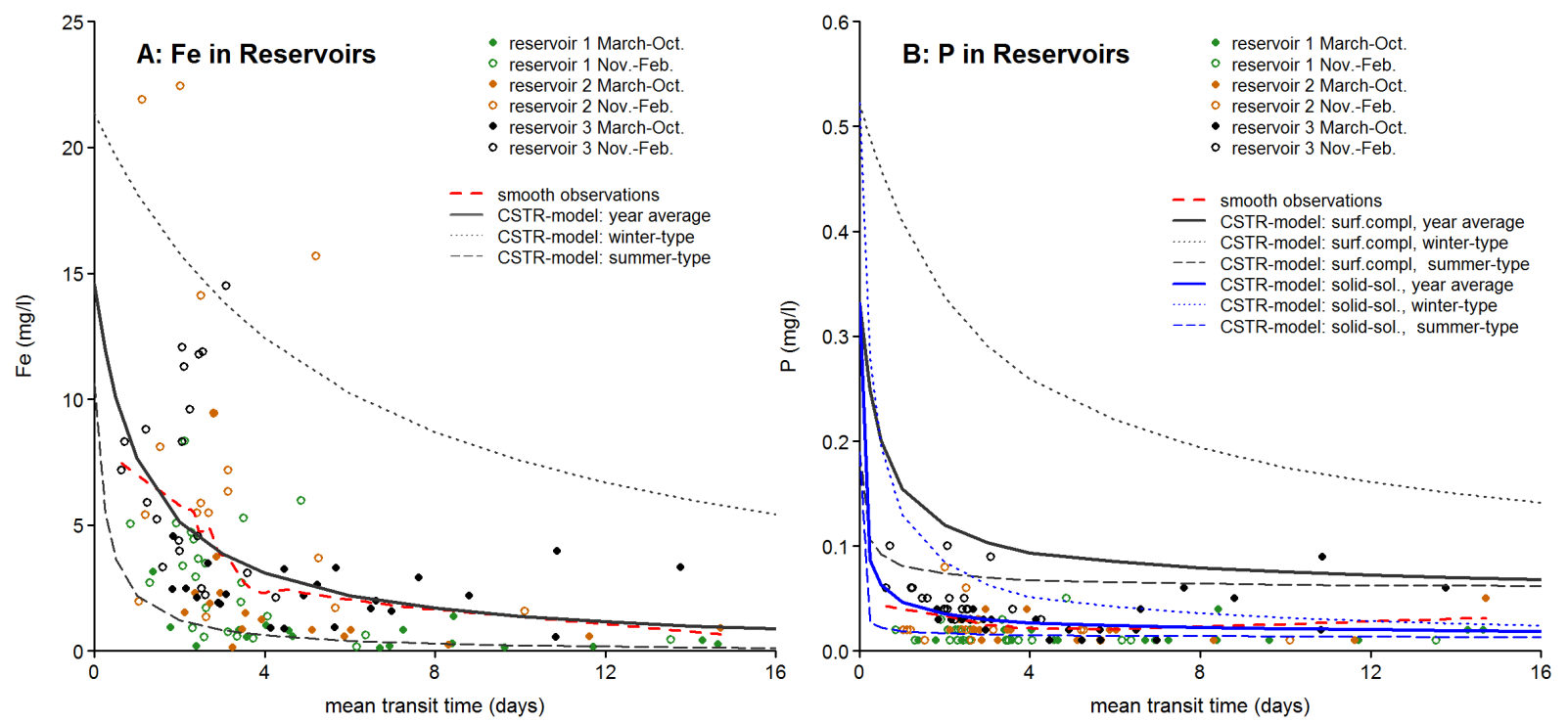

Figure 6. Measured $\mathrm{Fe}$ and $\mathrm{P}$ concentrations vs. the mean transit time of the water in the reservoirs. The blue and grey lines show the steady-state $\mathrm{Fe}$ and $\mathrm{P}$ concentrations according to the CSTR models as function of the mean transit time for the yearly average situation $\left(T=9.3{ }^{\circ} \mathrm{C} ; \mathrm{pH}=6.32 ; P_{\mathrm{O}_{2}}=0.21\right)$, the winter-type conditions $\left(T=5{ }^{\circ} \mathrm{C} ; \mathrm{pH}=6.17 ; P_{\mathrm{O}_{2}}=0.21\right.$ atm $)$ and summer-type conditions $\left(T=17^{\circ} \mathrm{C} ; \mathrm{pH}=6.53 ; P_{\mathrm{O}_{2}}=0.1 \mathrm{~atm}\right)$.

resulted in higher $\mathrm{pH}$ values during summer. In contrast to $\mathrm{CO}_{2}$ degassing, hydrolysis following oxidation of $\mathrm{Fe}(\mathrm{II})$ to $\mathrm{Fe}(\mathrm{III})$ generates acidity. This reduces the alkalinity of water and tempers the $\mathrm{pH}$ increase following $\mathrm{CO}_{2}$ degassing. Modelling calculations with PHREEQC indicated that oxygenation and degassing of groundwater with a $\mathrm{pH}$ of $6.16, \mathrm{Fe}(\mathrm{II})$ concentration of $15.9 \mathrm{mg} \mathrm{L}^{-1}$, and $P_{\mathrm{CO}_{2}}$ of $0.056 \mathrm{~atm}$ to the summer-average $P_{\mathrm{CO}_{2}}$ of the reservoir water of 0.024 atm results in $\mathrm{pH}$ values of 6.54 and 6.39 without and with oxidative hydrolysis, respectively. These $\mathrm{pH}$ values are somewhat lower than a majority of $\mathrm{pH}$ measurements of the reservoir water during the summer months (Fig. 4). So degassing of the surface water is not the only process that induces the seasonal $\mathrm{pH}$ increase.

The transit time of the water in the reservoirs also explains the low Fe concentrations in the summer months. Figure 6a shows that the measured concentrations decrease with an increase of the mean transit time, although a large variation of the $\mathrm{Fe}$ concentrations around the variable span smoother exists. Iron concentrations higher than $5 \mathrm{mg} \mathrm{L}^{-1}$ were only found when the residence time was less than 5 days. Samples from November to February have predominantly residence times shorter than 5 days and $\mathrm{Fe}$ concentrations above the smoother line. The Fe concentrations of samples from March to October were predominantly lower than the smoother line.

\subsubsection{Tube drains}

The increase in Fe concentration of tube drain 3 indicates a change in the redox status of the drained water. The flow data of the tube drains showed a decrease of the discharge rate of drain 3 starting in December 2007 (Fig. S4). This indicates that the redox change was caused by clogging of the tube drain due to precipitation of Fe oxyhydroxides in combination with the growth of microbial biomass in the tube drain. Clogging results in an increase of the water saturation of the tube drain and therefore in a decrease of atmospheric oxygen penetration in the tube drain itself and the surrounding soil. The Fe oxidation, therefore, no longer occurs in the tube drain or the surrounding soil but after groundwater is discharged to the ditch. Clogging of filter material at redox boundaries is a common phenomenon for example in drilled wells for groundwater abstraction and also tube drains (Houot and Berthelin, 1992; Van Beek et al., 2009; Wolthoorn et al., 2004).

\subsubsection{Surface water}

Unlike the water in the reservoirs, the Fe concentrations of the surface water samples from the sub-catchment outlet and the catchment outlet ranges year-round around $1 \mathrm{mg} \mathrm{L}^{-1}$. This is the value range that is commonly found in (oxygenated) surface water in the Netherlands. For example, $\mathrm{Fe}$ concentration in filtered stream and ditch water samples in the FOREGS database for the Netherlands ranges between 0.014 and $0.787 \mathrm{mg} \mathrm{L}^{-1}$ (Salminen, 2005). This indicates that the $\mathrm{Fe}$ (II) from the groundwater is completely oxidized at these sampling locations. The absence of water with $\mathrm{Fe}$ concentrations in the range of the reservoir water is explained by the longer residence time of the surface water at the sub-catchment and catchment outlet and by contributions of the dominantly aerobic Fe-depleted tube drain water 
to the surface water discharge. Tube drain water was physically separated from the groundwater at our experimental field and, therefore, did not contribute to the inflow to the reservoirs. Van der Velde et al. (2010) concluded that during normal flow conditions, the tile drain contribution to surface water discharge is more important than the groundwater contribution.

Although ranging around $1 \mathrm{mg} \mathrm{L}^{-1}$, the $\mathrm{Fe}$ concentrations of the surface water samples were higher than concentrations predicted by assuming equilibrium of Fe(III) with a Fe oxyhydroxide phase.

\subsection{Fe oxidation kinetics}

The second objective of our study was to infer reaction rates and mechanisms that influence the Fe oxidation process. The kinetic oxidation of dissolved $\mathrm{Fe}(\mathrm{II})$ was modelled according the general rate law as reported by Stumm and Lee (1961). The Fe oxidation rates inferred from our field measurements closely agree with the general rate law for abiotic oxidation of $\mathrm{Fe}$ (II) by $\mathrm{O}_{2}\left(k=7.9 \times 10^{13} \mathrm{M}^{-2} \mathrm{~atm}^{-1} \mathrm{~min}^{-1}\right)$ (Fig. 6a). Seasonal changes in $\mathrm{pH}$ and temperature of the reservoir water had a major effect on the $\mathrm{Fe}$ (II) oxidation rate as explained below.

The grey lines in Fig. 6a represent the steady-state Fe(II) concentration as a function of the mean transit times as calculated with the CSTR model. The model simulates the Fe(II) oxidation in the reservoirs for the yearly average conditions, a typical summer situation, and a typical winter situation. Table 2 gives the input parameters for the CSTR model. The Fe concentration of the groundwater (Fig. 2a) was used as inflow concentration $\left(\mathrm{Fe}_{i}\right.$ in Eq. 2) to the reservoir. This is variable in space and time between 0.2 and $40 \mathrm{mg} \mathrm{L}^{-1}$. Because we do not know the values of $\mathrm{Fe}_{i}$ at sampling moments exactly, it was not possible to derive field-based oxidation rates for the individual measured $\mathrm{Fe}$ concentrations. The $\mathrm{Fe}$ concentration of the groundwater that flows into the reservoirs $\left(\mathrm{Fe}_{i}\right)$ was set to $14.5 \mathrm{mg} \mathrm{L}^{-1}$ representing the median concentration of $\mathrm{Fe}$ in the groundwater. The median concentration was preferred above the average concentration due to the skewness of the Fe concentration distribution to high values. The thin lines in Fig. 6a represent a typical summer and winter situation. The $\mathrm{Fe}_{i}$ for the summer and winter situations were set to the 25-percentile and 75percentile of $\mathrm{Fe}$ concentration in the groundwater (10.6 and $21.3 \mathrm{mg} \mathrm{L}^{-1}$, respectively). The input values for the rate controlling parameters were assigned as follows: (1) the $\mathrm{pH}$ values are calculated from the yearly averaged and seasonally averaged $\left[\mathrm{H}^{+}\right]$measurements from the reservoirs $(6.31,6.17$ and 6.53, respectively); (2) biological, chemical and physical processes control the dissolved oxygen concentration of drainage ditches (Kersting and Kouwenhoven, 1989). Therefore the oxygen concentration of our reservoirs will be variable over the year and even over the day. However, low oxygen saturation levels or even hypoxia are not likely for the
Table 2. Input parameters for the CSTR model.

\begin{tabular}{lcccll}
\hline & $\begin{array}{c}\text { Fe inflow } \\
\left(\mathrm{mg} \mathrm{L}^{-1}\right)\end{array}$ & $\begin{array}{c}\mathrm{PO}_{4} \text { inflow } \\
\left(\mathrm{mg} \mathrm{L}^{-1}\right)\end{array}$ & $\mathrm{pH}$ & $\begin{array}{l}P_{\mathrm{O}_{2}} \\
(\mathrm{~atm})\end{array}$ & $\begin{array}{l}T \\
\left({ }^{\circ} \mathrm{C}\right)\end{array}$ \\
\hline Year average & 14.5 & 0.33 & 6.32 & 0.21 & 9.3 \\
Summer situation & 10.6 & 0.19 & 6.56 & 0.1 & 17 \\
Winter situation & 21.3 & 0.52 & 6.17 & 0.21 & 5 \\
\hline
\end{tabular}

reservoir water. Hypoxia is not an uncommon phenomenon in ditches with free-floating plant mats (Verdonschot and Verdonschot, 2014; Kersting and Kouwenhoven, 1989) but this was not the situation for our reservoirs. Moreover, because of a high degree of atmosphere-water contact (the reservoirs have typically a small wetted volume as opposed to its wetted perimeter) equilibrium with atmospheric oxygen might be possible. In the winter situation we assume that the equilibrium time to reach complete saturation is less than the half-life time of $\mathrm{Fe}(\mathrm{II})$. Therefore, we used complete oxygen saturation $\left(P_{\mathrm{O}_{2}}=0.21 \mathrm{~atm}\right)$ for the winter situation. The $\mathrm{Fe}(\mathrm{II})$ oxidation rate is clearly higher in the summer situation. The $\mathrm{Fe}(\mathrm{II})$ is presumably completely oxidized before the reservoir water is in equilibrium with atmospheric oxygen. For this reason we modelled the reaction for the summer situation with a $P_{\mathrm{O}_{2}}$ of $0.1 \mathrm{~atm}$; (3) the temperature for the yearly average model was set to the yearly averaged temperature of the ditch water $\left(9.3^{\circ} \mathrm{C}\right)$ and to 17 and $5{ }^{\circ} \mathrm{C}$ for the summer and winter situation respectively (Fig. 5).

Figure 6a shows that the variable span smoother through the observations matches with the model for the yearly average conditions. Although our modelled reaction rate might probably slightly be overestimated due to the presence of colloidal $\mathrm{Fe}(\mathrm{III})$ in the reservoir water samples we may safely conclude that the decrease of the $\mathrm{Fe}$ concentration with increasing mean transit time of the water in the reservoirs closely agreed with the reported rate law of abiotic $\mathrm{Fe}$ (II) oxidation in laboratory systems with a rate constant of $7.9 \times 10^{13} \mathrm{M}^{-2} \mathrm{~atm}^{-1} \mathrm{~min}^{-1}$ (Stumm and Lee, 1961). Most measured $\mathrm{Fe}$ concentrations fall between the summer-type and winter-type lines. The winter-type model seems to underestimate the $\mathrm{Fe}$ (II) oxidation rate slightly. This is likely due to microbial $\mathrm{Fe}(\mathrm{II})$ oxidation that become increasingly important when abiotic rates are retarded by low temperatures (de Vet et al., 2011), like in our winter situation. Although microbial Fe(II) oxidation at low oxygen concentration and autocatalytic Fe(II) oxidation due to adsorption of $\mathrm{Fe}(\mathrm{II})$ onto surfaces of previously formed $\mathrm{Fe}(\mathrm{III})$ oxyhydroxides may happen in the reservoirs, enhanced reaction rates caused by these processes were not considered in our model. The effect of autocatalytic $\mathrm{Fe}$ (II) oxidation on the reaction rate is currently under debate. Sung and Morgan (1980) concluded that autocatalytic $\mathrm{Fe}$ (II) oxidation is only observed in experiments with a $\mathrm{pH}$ of 7 and higher. However, Pedersen et al. (2005) showed that $\mathrm{Fe}$ (II) can interact with $\mathrm{Fe}$ (III) oxyhydroxides surfaces and can be oxidized at $\mathrm{pH}$ 6.5. Schaefer 
et al. (2010) showed that the electron transfer between dissolved Fe(II) and structural Fe(III) can occur at the surface of $\mathrm{Fe}(\mathrm{III})$-bearing clay minerals such as smectite. Moreover, Vollrath et al. (2012) argue that the rate law originally proposed by Stumm and Lee (1961) was already influenced by surface catalysis and, therefore, not strictly represents homogeneous Fe(II) oxidation.

The large difference between the summer-type and wintertype model illustrates the effect of the temperature and $\mathrm{pH}$ on the abiotic Fe(II) oxidation rate. Figure 6a makes clear that the oxidation of $\mathrm{Fe}$ in anaerobic groundwater after being discharged into surface water is not instantaneous. It will take a couple of days to more than a week before complete oxidation of $\mathrm{Fe}$ (II) is reached, especially under winter conditions.

\subsection{Behaviour of $P$}

The third objective was to measure the dynamics in $\mathrm{P}$ concentrations and to explore the phosphate immobilization process during flow of anaerobic iron-rich groundwater towards surface water. Our field data show that dissolved P preferentially precipitates from solution during the initial stage of the $\mathrm{Fe}(\mathrm{II})$ oxidation process. When high $\mathrm{Fe}$ concentrations happened in the reservoir water and the water from tube drain 3, substantially lower $\mathrm{P}$ concentrations were found in these waters compared to the groundwater. The average molar $\mathrm{P} / \mathrm{Fe}$ ratios of the reservoir water and tube drain 3 varied between 0.004 and 0.014 during winter time (Table 1); this is distinctly lower than the $\mathrm{P} / \mathrm{Fe}$ ratio in the groundwater that varied between 0.016 and 0.079 . A single $\mathrm{Fe}$-oxide flocs sample from a drain had a molar $\mathrm{P} / \mathrm{Fe}$ ratio of 0.033 . This is in the range of the groundwater $\mathrm{P} / \mathrm{Fe}$ ratio. Moreover, there is no relation between the $\mathrm{P}$ concentration of the reservoir water and the mean transit time (Fig. 6b) and no clear seasonal dynamics in $\mathrm{P}$ concentrations in the water other than groundwater exist into and there are no clear seasonal dynamics in $\mathrm{P}$ concentrations in the water other than groundwater (Fig. 3). For tube drain 3, two mechanisms might cause these observations: (1) the average $P$ concentration of the anaerobic groundwater that flowed into the tube drain was lower than the groundwater sampled from the four wells or (2) there was continuous immobilization of dissolved $\mathrm{P}$ in tube drain 3 despite the observation that complete oxidation of Fe no longer occurred in this drain. For the reservoirs, it is not likely that the inflow of groundwater with low $\mathrm{P}$ concentrations determined the $\mathrm{P}$ concentration of this water. After all, the groundwater was sampled from four wells parallel to the reservoirs covering almost the entire stretch of the reservoirs. So the observations point to a rapid transformation of dissolved $\mathrm{P}$ to structural $\mathrm{P}$ during the initial stage of $\mathrm{Fe}(\mathrm{II})$ oxidation along the flow-path of groundwater into surface water. This resulted in nearly complete $\mathrm{P}$ depletion in the water before Fe(II) was depleted.

The blue and grey lines in Fig. $6 \mathrm{~b}$ are the steady-state $\mathrm{P}$ concentration according to the two CSTR models for phosphate immobilization as a function of the mean transit time. The models simulates the binding of phosphate by surface complexation to $\mathrm{Fe}$ oxyhydroxide precipitates that formed during $\mathrm{Fe}(\mathrm{II})$ oxidation and precipitation of a solidsolution between amorphous $\mathrm{Fe}$ hydroxide $\left(\mathrm{Fe}(\mathrm{OH})_{3}\right)$ and strengite $\left(\mathrm{FePO}_{4} \cdot 2 \mathrm{H}_{2} \mathrm{O}\right)$. The $\mathrm{P}$ concentrations of the inflow water were set to $0.33,0.52$ and $0.19 \mathrm{mg} \mathrm{L}^{-1}$ representing the median, 75-percentile and 25-percentile of $\mathrm{P}$ concentration in the groundwater (Table 2). Figure $6 \mathrm{~b}$ indicates clearly that the measured $\mathrm{P}$ concentrations are distinctly lower than the concentrations according to the surface complexation model for the whole range of mean transit times. The immobilization of P during aeration of groundwater could not solely be attributed to surface complexation to a Fe-oxide type of phase. The concentrations according to the model that simulate the precipitation of a solid-solution between amorphous Fe hydroxide and strengite are in the range of the measured concentrations. The variable span smoother through the observations matches with the model for the year average conditions. The fast immobilization of $\mathrm{P}$ during the short mean transit times, where $\mathrm{Fe}(\mathrm{II})$ was still present in high concentration, could satisfactory be described by the model. This indicates the formation of $\mathrm{Fe}(\mathrm{III})$-phosphate precipitates during the initial stage of $\mathrm{Fe}(\mathrm{II})$ oxidation until phosphate is depleted from solution. The model overestimates the lowest measured $\mathrm{P}$ concentration. This could be attributed to additional adsorption of phosphate to the Fe-oxides that were as well formed in the solid-solution or by uncertainty in the $\log \mathrm{K}$ value of strengite.

Recently, Voegelin et al. (2013) studied the effect of phosphate on the formation of Fe precipitates upon oxidation of $\mathrm{Fe}(\mathrm{II})$ at near-neutral $\mathrm{pH}$. Their data verify that $\mathrm{Fe}$ (II) oxidation initially results in the precipitation of a phosphate-rich Fe-precipitate whose $\mathrm{P} / \mathrm{Fe}$ ratio reaches $\sim 0.52$ at the time of near-complete phosphate depletion from solution. This is supported by a limited number of studies (Deng, 1997; Gunnars et al., 2002) which indicated that during Fe(II) oxidation in solutions with initial dissolved $\mathrm{P} / \mathrm{Fe}$ ratio less than $\sim 0.5$, a phosphate-rich precipitate with molar $\mathrm{P} / \mathrm{Fe}$ ratio of $\sim 0.5-0.6$ forms first. Rather than a simple formation of $\mathrm{Fe}(\mathrm{III})$-hydroxide coupled with competitive ion adsorption, Voegelin et al. (2013) concluded that several types of Fe(III)precipitates may form and transform over the course of $\mathrm{Fe}(\mathrm{II})$ oxidation in the presence of phosphate. $\mathrm{Fe}(\mathrm{III})$-phosphate, phosphate-saturated hydrous ferric oxide, goethite and lepidocrocite were successively formed in their study depending on the dissolved molar $\mathrm{P} / \mathrm{Fe}$ ratios. The observations from our experimental field site are thus supported by laboratory experiments on synthetic samples. 

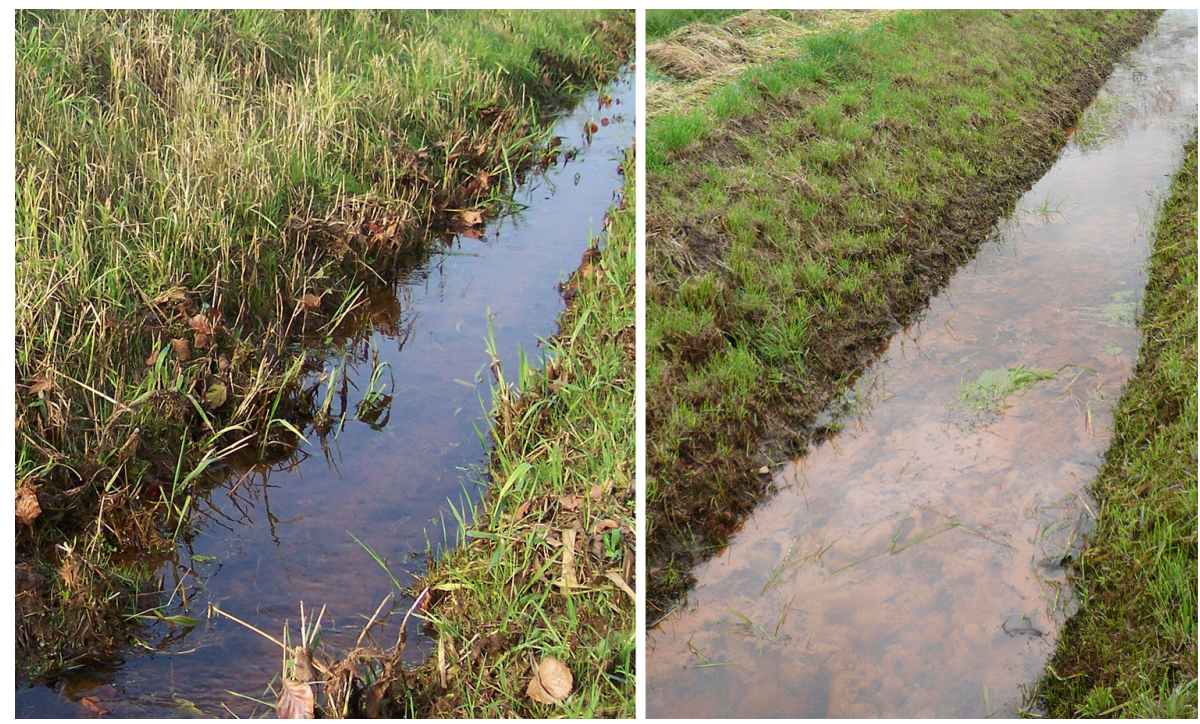

Figure 7. Pictures of the field ditch in the late summer (left panel) and winter (right panel). The red sediment indicates the presence of iron hydroxides in the winter situation. These were absent in summer.

\subsection{Implications}

\subsubsection{Dynamics in the redox gradient}

The higher Fe concentration of the reservoir water during winter compared to summer are explained by a reduction of the $\mathrm{Fe}(\mathrm{II})$ oxidation rate combined with an increased inflow of groundwater into the reservoirs during winter. Based on our data, we argue that the oxidation rate of $\mathrm{Fe}(\mathrm{II})$ in combination with groundwater inflow to the ditch is such that the $\mathrm{Fe}(\mathrm{II})$ oxidation occurs at the sediment-water interface or deeper in the soil domain during summer, resulting in low $\mathrm{Fe}(\mathrm{II})$ concentrations of the reservoir water (Fig. 2c). Fe(II) oxidation shifts to the surface water in winter evidenced by high Fe(II) concentrations. This argument is supported by visual observations of the ditch water during the field experiment. The easily resuspendable Fe-oxide flocs which have sedimented on ditch bottoms were predominantly found in winter time (Fig. 7). So, the position of the redox gradient in the groundwater-surface water interface of our experimental field is dynamic in time as a result of dynamics in hydrological and biogeochemical conditions. Krause et al. (2009) measured highly complex temporal changes in redox status and pore water nitrate concentrations at the groundwater-surface water interface of a small river. Maassen and Balla (2010) measured the effect of these redox dynamics on phosphorus mobilization from the sediment to the surface water. We show that dynamics in redox processes as well may impact the Fe(II) oxidation process and phosphorus immobilization during flow from groundwater into surface water.

Due to deeper groundwater tables in summer oxygensaturated surface water may start to infiltrate and atmospheric oxygen may penetrate the soil surrounding the tube drains.
Through higher groundwater tables and more discharge this oxygen-saturated water is flushed out again in winter time. Moreover, the abundant growth of grasses and reeds inside the ditches is likely to actively transfer oxygen through the groundwater-surface water interface during summer time. In a previous experiment at the same field site an iron-rich zone was observed directly around the drain tube, causing an orange-coloured "ring" in the soil around the tube drain (Van den Eertwegh, 2002). The P content of the solid material in this ring was three times higher than for soil samples taken just outside this iron-rich zone. Although the Fe content of the soil samples and the $\mathrm{P}$ concentrations of the groundwater were not measured, this indicates at least a partial retardation of dissolved $\mathrm{P}$ in this soil domain.

\subsubsection{Suspended sediment}

The formation of Fe-oxide flocs in the surface water will contribute to the suspended sediment concentration of this surface water. The origin of suspended sediments and particulate-bound $\mathrm{P}$ in agricultural catchments is widely studied (Ballantine et al., 2008; Walling et al., 2008). Traditionally, two source types of suspended sediment are being distinguished: surface erosion and resuspension of streambed sediment. Rainstorm events and high discharge peaks are commonly considered as the trigger for mobilization of these source materials (Horowitz, 2008). Little attention has been paid to the formation of authigenic sediment in the surface water systems formed by exfiltration and oxygenation of anaerobic groundwater. However, we argue that it may be an important suspended sediment source in areas draining anaerobic groundwater. The only studies, known to us, on authigenic sediments in freshwater systems formed 
by oxidation of iron-rich groundwater are from Baken et al. (2013) and Vanlierde et al. (2007). They reported an average annual authigenic mineral contribution to the total suspended sediment flux between 31 and $75 \%$ for a catchment in Belgium. Based on the Hupsel field experiment data, we argue that the formation of authigenic suspended sediments in the surface water domain predominantly occurs in winter time and that this attributes to an increase in the turbidity of surface water combined with a change in colour of the surface water compared to the summer situation.

\subsubsection{Remobilization of phosphate}

Finally, the question arises of what the effect of the preferential $\mathrm{P}$ precipitation during oxidation of $\mathrm{Fe}(\mathrm{II})$ will be on phosphate retention. The formation of Fe(III)-phosphate precipitates during oxygenation of groundwater in the soil surrounding the ditch or tube drain may result in permanent retention of phosphate at the transition zone from groundwater into surface water. However, the structural $\mathrm{P}$ stored in this zone may be discharged to the surface water by erosion during high flow conditions or remobilized to dissolved $\mathrm{P}$ by reductive dissolution or aging of Fe(III) precipitates. Thus, the transformation of the Fe precipitates may result in the release of dissolved phosphate. A limited number of time-resolved experiments addressed the effect of transformation processes. All measured an increase in dissolved phosphate (Mayer and Jarrell, 2000; Gerke, 1993; Voegelin et al., 2013). Voegelin et al. (2013) attributed this phosphate release to ongoing $\mathrm{Fe}$ (III) polymerization into (crystalline) $\mathrm{Fe}(\mathrm{III})$-(hydr)oxides combined with no further Fe(III) supply to the solid phase that could have retained phosphate. The question remains whether this phosphate release process due to aging of minerals occurs in the natural environment as well at these reported levels. After all, there is an ongoing Fe(II) supply in the natural environment resulting in the formation of new $\mathrm{Fe}$ (III) precipitates. Moreover, solutes such as silicate or humic acid interfere with $\mathrm{Fe}(\mathrm{III})$ polymerization and may markedly slow down $\mathrm{Fe}$ (III) polymerization, phase transformation and associated phosphate release (Gerke, 1993; Mayer and Jarrell, 2000).

\section{Conclusions}

This field study demonstrates that: (1) the Fe concentrations of water in in-stream reservoirs capturing exfiltrating anaerobic groundwater and the tube drain water were dynamic over the year. The Fe concentrations of the water in the reservoirs were high and reached the levels of the groundwater in winter time and were low in summer time. This indicates seasonal changes in the $\mathrm{Fe}(\mathrm{II})$ oxidation rate. The dissolved $\mathrm{P}$ concentration of the reservoir water and tube drain water were an order of magnitude lower than observed in the groundwater throughout the year. Seasonal changes in the Fe(II) oxidation rate had no impact on the P immobilization; (2) the $\mathrm{Fe}(\mathrm{II})$ oxidation rate at our field site closely agrees with reported rate laws for abiotic oxidation of $\mathrm{Fe}(\mathrm{II})$ by $\mathrm{O}_{2}$. Due to a lower $\mathrm{pH}$ and temperature the $\mathrm{Fe}$ (II) oxidation rates are lower in winter time compared to summer time. Combined with higher groundwater fluxes during winter this likely resulted in a shift from $\mathrm{Fe}$ (II) oxidation occurring in the soil or ditch sediment in summer time to the surface water in winter time; (3) phosphorus immobilization at our field site is much faster than the surface complexation model proposed by Dzombak and Morel (1990). This results in depletion of phosphate water before Fe(II) is depleted. The fast P immobilization could satisfactorily be described by the precipitation of a solid-solution between amorphous $\mathrm{Fe}$ hydroxide and strengite (Fe(III)-phosphate). The formation of Fe(III)phosphates at redox gradients seems to be an important biogeochemical mechanism in the transformation of dissolved phosphate to structural phosphate and, therefore, a major control on the phosphate retention in streams and ditches that drain anaerobic groundwater.

\section{The Supplement related to this article is available online at doi:10.5194/hess-11-4687-2014-supplement.}

Acknowledgements. The authors would like to thank Søren Jessen and Steeve Bonneville for their valuable comments and suggestions, which have greatly improved this paper. We would like to acknowledge Deltares for financing this study.

Edited by: P. Regnier

\section{References}

Allard, T., Menguy, N., Salomon, J., Calligaro, T., Weber, T., Calas, G., and Benedetti, M. F.: Revealing forms of iron in river-borne material from major tropical rivers of the Amazon Basin (Brazil), Geochim. Cosmochim. Acta, 68, 3079-3094, doi:10.1016/j.gca.2004.01.014, 2004.

Baken, S., Sjöstedt, C., Gustafsson, J. P., Seuntjens, P., Desmet, N., De Schutter, J., and Smolders, E.: Characterisation of hydrous ferric oxides derived from iron-rich groundwaters and their contribution to the suspended sediment of streams, Appl. Geochem., 39, 59-68, doi:10.1016/j.apgeochem.2013.09.013, 2013.

Ball, J. W. and Nordstrom, D. K.: User's manual for WATEQ4F, with revised thermodynamic data base and text cases for calculating speciation of major, trace, and redox elements in natural waters, US Geological Survey Menlo Park, California, USA, 1991.

Ballantine, D. J., Walling, D. E., Collins, A. L., and Leeks, G. J. L.: The phosphorus content of fluvial suspended sediment in three lowland groundwater-dominated catchments, J. Hydrol., 357, 140-151, 2008. 
Benedetti, M. F., Ranville, J. F., Allard, T., Bednar, A. J., and Menguy, N.: The iron status in colloidal matter from the Rio Negro, Brasil, Colloids Surf. A, 217, 1-9, doi:10.1016/S09277757(02)00553-8, 2003.

Bonte, M.: Impacts of shallow geothermal energy on groundwater quality A hydrochemical and geomicrobial study of the effects of ground source heat pumps and aquifer thermal energy storage, Ph.D., Ph.D. thesis, Vrije Universiteit Amsterdam, Amsterdam, the Netherlands, 2013.

Botter, G., Bertuzzo, E., and Rinaldo, A.: Catchment residence and travel time distributions: The master equation, Geophys. Res. Lett., 38, L11403, doi:10.1029/2011GL047666, 2011.

Carlyle, G. C. and Hill, A. R.: Groundwater phosphate dynamics in a river riparian zone: effects of hydrologic flowpaths, lithology and redox chemistry, J. Hydrol., 247, 151-168, 2001.

Chardon, W. J., Aalderink, G. H., and Van Der Salm, C.: Phosphorus leaching from cow manure patches on soil columns, J. Environ. Qual., 36, 17-22, 2007.

Châtellier, X., West, M. M., Rose, J., Fortin, D., Leppard, G. G., and Ferris, F. G.: Characterization of iron-oxides formed by oxidation of ferrous ions in the presence of various bacterial species and inorganic ligands, Geomicrobiol. J., 21, 99-112, 2004.

Dahlke, H. E., Easton, Z. M., Lyon, S. W., Todd Walter, M., Destouni, G., and Steenhuis, T. S.: Dissecting the variable source area concept - .Subsurface flow pathways and water mixing processes in a hillslope, J. Hydrol., 420-421, 125-141, 2012.

Dahm, C. N., Grimm, N. B., Marmonier, P., Valett, H. M., and Vervier, P.: Nutrient dynamics at the interface between surface waters and groundwaters, Freshwater Biol., 40, 427-451, doi:10.1046/j.1365-2427.1998.00367.x, 1998.

Deng, Y.: Formation of iron(III) hydroxides from homogeneous solutions, Water Res., 31, 1347-1354, 1997.

Deppe, T. and Benndorf, J.: Phosphorus reduction in a shallow hypereutrophic reservoir by in-lake dosage of ferrous iron, Water Res., 36, 4525-4534, doi:10.1016/S0043-1354(02)00193-8, 2002.

de Vet, W. W. J. M., Dinkla, I. J. T., Rietveld, L. C., and van Loosdrecht, M. C. M.: Biological iron oxidation by Gallionella spp. in drinking water production under fully aerated conditions, Water Res., 45, 5389-5398, 2011.

Dunne, E. J., Reddy, K. R., and Clark, M. W.: Phosphorus release and retention by soils of natural isolated wetlands, Int. J. Environ. Poll., 28, 496-516, 2006.

Dzombak, D. A. and Morel, F. M.: Surface complexation modeling: hydrous ferric oxide, Wiley, New York, 1990.

Elser, J. J., Bracken, M. E. S., Cleland, E. E., Gruner, D. S., Harpole, W. S., Hillebrand, H., Ngai, J. T., Seabloom, E. W., Shurin, J. B., and Smith, J. E.: Global analysis of nitrogen and phosphorus limitation of primary producers in freshwater, marine and terrestrial ecosystems, Ecol. Lett., 10, 1135-1142, doi:10.1111/j.14610248.2007.01113.x, 2007.

Fox, L. E.: A model for inorganic control of phosphate concentrations in river waters, Geochim. Cosmochim. Acta, 53, 417-428, 1989.

Frei, S., Knorr, K. H., Peiffer, S., and Fleckenstein, J. H.: Surface micro-topography causes hot spots of biogeochemical activity in wetland systems: A virtual modeling experiment, J. Geophys. Res.-Biogeo., 117, G00N12, doi:10.1029/2012JG002012, 2012.
Friedman, J. H.: A variable span scatterplot smoother, Laboratory for Computational Statistics, Stanford University, Stanford University Technical Report No. 5, Stanford, 1984.

Gerke, J.: Phosphate adsorption by humic/Fe-oxide mixtures aged at $\mathrm{pH} 4$ and 7 and by poorly ordered Fe-oxide, Geoderma, 59, 279-288, 1993.

Griffioen, J.: Extent of immobilisation of phosphate during aeration of nutrient-rich, anoxic groundwater, J. Hydrol., 320, 359-369, doi:10.1016/j.jhydrol.2005.07.047, 2006.

Griffioen, J., Vermooten, S., and Janssen, G.: Geochemical and palaeohydrological controls on the composition of shallow groundwater in the Netherlands, Appl. Geochem., 39, 129-149, doi:10.1016/j.apgeochem.2013.10.005, 2013.

Gunnars, A., Blomqvist, S., Johansson, P., and Andersson, C.: Formation of $\mathrm{Fe}$ (III) oxyhydroxide colloids in freshwater and brackish seawater, with incorporation of phosphate and calcium, Geochim. Cosmochim. Acta, 66, 745-758, 2002.

Hayashi, M. and Yanagi, T.: Water and phosphorus budgets in the Yellow River estuary including the submarine fresh groundwater, in: From Headwaters to the Ocean: Hydrological Change and Water Management - Proceedings of the International Conference on Hydrological Changes and Management from Headwaters to the Ocean, Hydrochange 2008, 1-3 October 2009, Kyoto, Japan, 665-668, 2009.

Holman, I. P., Whelan, M. J., Howden, N. J. K., Bellamy, P. H., Willby, N. J., Rivas-Casado, M., and McConvey, P.: Phosphorus in groundwater - an overlooked contributor to eutrophication?, Hydrol. Process., 22, 5121-5127, doi:10.1002/hyp.7198, 2008.

Horowitz, A. J.: Determining annual suspended sediment and sediment-associated trace element and nutrient fluxes, Sci. Total Environ., 400, 315-343, doi:10.1016/j.scitotenv.2008.04.022, 2008.

Houot, S. and Berthelin, J.: Submicroscopic studies of iron deposits occurring in field drains: formation and evolution, Geoderma, 52, 209-222, 1992.

House, W. A. and Denison, F. H.: Nutrient dynamics in a lowland stream impacted by sewage effluent: Great Ouse, England, Sci. Total Environ., 205, 25-49, doi:10.1016/S0048-9697(97)000867, 1997.

Hug, S. J. and Leupin, O.: Iron-Catalyzed Oxidation of Arsenic(III) by Oxygen and by Hydrogen Peroxide:? pH-Dependent Formation of Oxidants in the Fenton Reaction, Environ. Sci. Technol., 37, 2734-2742, doi:10.1021/es026208x, 2003.

Jordan, P., Melland, A. R., Mellander, P. E., Shortle, G., and Wall, D.: The seasonality of phosphorus transfers from land to water: Implications for trophic impacts and policy evaluation, Sci. Total Environ., 434, 101-109, 2012.

Kaegi, R., Voegelin, A., Folini, D., and Hug, S. J.: Effect of phosphate, silicate, and $\mathrm{Ca}$ on the morphology, structure and elemental composition of $\mathrm{Fe}$ (III)-precipitates formed in aerated $\mathrm{Fe}$ (II) and As(III) containing water, Geochim. Cosmochim. Acta, 74, 5798-5816, doi:10.1016/j.gca.2010.07.017, 2010.

Kersting, K. and Kouwenhoven, P.: Annual and diel oxygen regime in two polder ditches, Hydrobiolog. Bull., 23, 111-123, doi:10.1007/BF02256728, 1989.

Krause, S., Heathwaite, L., Binley, A., and Keenan, P.: Nitrate concentration changes at the groundwater-surface water interface of a small Cumbrian river, Hydrol. Process., 23, 2195-2211, 2009. 
Lienemann, C. P., Monnerat, M., Janusz, D., and Perret, D.: Identification of stoichiometric iron-phosphorus colloids produced in a eutrophic lake, Aquat. Sci., 61, 133-149, 1999.

Lofts, S., Tipping, E., and Hamilton-Taylor, J.: The Chemical Speciation of Fe(III) in Freshwaters, Aquat. Geochem., 14, 337-358, doi:10.1007/s10498-008-9040-5, 2008.

Lyvén, B., Hassellöv, M., Turner, D. R., Haraldsson, C., and Andersson, K.: Competition between iron- and carbon-based colloidal carriers for trace metals in a freshwater assessed using flow fieldflow fractionation coupled to ICPMS, Geochim. Cosmochim. Acta, 67, 3791-3802, doi:10.1016/S0016-7037(03)00087-5, 2003.

Maassen, S. and Balla, D.: Impact of hydrodynamics (exand infiltration) on the microbially controlled phosphorus mobility in running water sediments of a cultivated northeast German wetland, Ecol. Eng., 36, 1146-1155, doi:10.1016/j.ecoleng.2010.01.009, 2010.

Macrae, M. L., Zhang, Z., Stone, M., Price, J. S., Bourbonniere, R. A., and Leach, M.: Subsurface mobilization of phosphorus in an agricultural riparian zone in response to flooding from an upstream reservoir, Can. Water Resour. J., 36, 293-311, doi:10.4296/cwrj3604810, 2011.

Mayer, T. D. and Jarrell, W. M.: Phosphorus sorption during iron(II) oxidation in the presence of dissolved silica, Water Res., 34, 3949-3956, doi:10.1016/S0043-1354(00)00158-5, 2000.

Meng, X., Korfiatis, G. P., Bang, S., and Bang, K. W.: Combined effects of anions on arsenic removal by iron hydroxides, Toxicol. Lett., 133, 103-111, doi:10.1016/S0378-4274(02)00080-2, 2002

Neal, C., Jarvie, H. P., Williams, R. J., Neal, M., Wickham, H., and Hill, L.: Phosphorus - calcium carbonate saturation relationships in a lowland chalk river impacted by sewage inputs and phosphorus remediation: an assessment of phosphorus self-cleaning mechanisms in natural waters, Sci. Total Environ., 282-283, 295-310, doi:10.1016/S0048-9697(01)00920-2, 2002.

Neal, C., Lofts, S., Evans, C. D., Reynolds, B., Tipping, E., and Neal, M.: Increasing Iron Concentrations in UK Upland Waters, Aquat. Geochem., 14, 263-288, doi:10.1007/s10498-008-9036$1,2008$.

Parkhurst, D. L. and Appelo, C.: User's guide to PHREEQC (Version 2): A computer program for speciation, batch-reaction, onedimensional transport, and inverse geochemical calculations, US Geological Survey, Denver, Colorado, USA, 1999.

Pedersen, H. D., Postma, D., Jakobsen, R., and Larsen, O.: Fast transformation of iron oxyhydroxides by the catalytic action of aqueous Fe(II), Geochim. Cosmochim. Acta, 69, 3967-3977, doi:10.1016/j.gca.2005.03.016, 2005.

Perry, R. H., Green, D. W., and Maloney, J. O.: Perry's Chemical Engineers' Handbook, McGraw-Hill Education, New York, 1997.

Reddy, K. R., Kadlec, R. H., Flaig, E., and Gale, P. M.: Phosphorus Retention in Streams and Wetlands: A Review, Crit. Rev. Environ. Sci. Technol., 29, 83-146, 1999.

Roberts, L. C., Hug, S. J., Ruettimann, T., Billah, M., Khan, A. W., and Rahman, M. T.: Arsenic Removal with Iron(II) and Iron(III) in Waters with High Silicate and Phosphate Concentrations, Environ. Sci. Technol., 38, 307-315, 2004.

Rozemeijer, J., Van Der Velde, Y., De Jonge, H., Van Geer, F., Broers, H. P., and Bierkens, M.: Application and evaluation of a new passive sampler for measuring average solute concentrations in a catchment scale water quality monitoring study, Environ. Sci. Technol., 44, 1353-1359, 2010a.

Rozemeijer, J. C., Van Der Velde, Y., Van Geer, F. C., De Rooij, G. H., Torfs, P. J. J. F., and Broers, H. P.: Improving load estimates for $\mathrm{NO}_{3}$ and $\mathrm{P}$ in surface waters by characterizing the concentration response to rainfall events, Environ. Sci. Technol., 44, 6305-6312, 2010b.

Rozemeijer, J. C., Van Der Velde, Y., McLaren, R. G., Van Geer, F. C., Broers, H. P., and Bierkens, M. F. P.: Integrated modeling of groundwater-surface water interactions in a tiledrained agricultural field: The importance of directly measured flow route contributions, Water Resour. Res., 46, W11537, doi:10.1029/2010WR009155, 2010c.

Salminen, R.: FOREGS Geochemical Atlas of Europe, Part 1 Background information, methodology and maps, Geological Survey of Finland, Espoo, Finland, 2005.

Scanlon, T. M., Kiely, G., and Amboldi, R.: Model determination of non-point source phosphorus transport pathways in a fertilized grassland catchment, Hydrol. Process., 19, 2801-2814, 2005.

Schaefer, M. V., Gorski, C. A., and Scherer, M. M.: Spectroscopic Evidence for Interfacial $\mathrm{Fe}$ (II)-Fe(III) Electron Transfer in a Clay Mineral, Environ. Sci. Technol., 45, 540-545, doi:10.1021/es102560m, 2010.

Sharpley, A. N., Kleinman, P. J. A., Heathwaite, A. L., Gburek, W. J., Folmar, G. J., and Schmidt, J. P.: Phosphorus loss from an agricultural watershed as a function of storm size, J. Environ. Qual., 37, 362-368, 2008.

Shenker, M., Seitelbach, S., Brand, S., Haim, A., and Litaor, M. I.: Redox reactions and phosphorus release in re-flooded soils of an altered wetland, Eur. J. Soil Sci., 56, 515-525, 2005.

Spiteri, C., Regnier, P., Slomp, C. P., and Charette, M. A.: $\mathrm{pH}-$ Dependent iron oxide precipitation in a subterranean estuary, J. Geochem. Explor., 88, 399-403, doi:10.1016/j.gexplo.2005.08.084, 2006.

Stumm, W. and Lee, G. F.: Oxygenation of Ferrous Iron, Indust. Eng. Chem., 53, 143-146, doi:10.1021/ie50614a030, 1961.

Sung, W. and Morgan, J. J.: Kinetics and product of ferrous iron oxygenation in aqueous systems, Environ. Sci. Technol., 14, 561-568, doi:10.1021/es60165a006, 1980.

Van Beek, C. G. E. M., Breedveld, R. J. M., Juhász-Holterman, M., Oosterhof, A., and Stuyfzand, P. J.: Cause and prevention of well bore clogging by particles, Hydrogeol. J., 17, 1877-1886, 2009.

Van den Eertwegh, G. A. P. H.: Water and Nutrient budgets at field and regional scale, travel times of drainage water and nutrient loads to surface water, Ph.D. thesis, Wageningen University, Wageningen, 2002.

Van der Velde, Y., Rozemeijer, J. C., de Rooij, G. H., van Geer, F. C., and Broers, H. P.: Field-Scale Measurements for Separation of Catchment Discharge into Flow Route Contributions, Vadose Zone J., 9, 25-35, doi:10.2136/vzj2008.0141, 2010.

Van Geen, A., Robertson, A. P., and Leckie, J. O.: Complexation of carbonate species at the goethite surface: implications for adsorption of metal ions in natural waters, Geochim. Cosmochim. Acta, 58, 2073-2086, 1994.

Vanlierde, E., De Schutter, J., Jacobs, P., and Mostaert, F.: Estimating and modeling the annual contribution of authigenic sediment to the total suspended sediment load in the 
Kleine Nete Basin, Belgium, Sediment. Geol., 202, 317-332, doi:10.1016/j.sedgeo.2007.05.003, 2007.

Verdonschot, R. M. and Verdonschot, P. M.: Shading effects of freefloating plants on drainage-ditch invertebrates, Limnology, 15, 225-235, doi:10.1007/s10201-013-0416-x, 2014.

Voegelin, A., Senn, A. C., Kaegi, R., Hug, S. J., and Mangold, S.: Dynamic Fe-precipitate formation induced by $\mathrm{Fe}(\mathrm{II})$ oxidation in aerated phosphate-containing water, Geochim. Cosmochim. Acta, 117, 216-231, 2013.

Vollrath, S., Behrends, T., and van Cappellen, P.: Oxygen Dependency of Neutrophilic Fe(II) Oxidation by Leptothrix Differs from Abiotic Reaction, Geomicrobiol. J., 29, 550-560, 2012.

von Gunten, U. and Schneider, W.: Primary products of the oxygenation of iron(II) at an oxic-anoxic boundary: Nucleation, aggregation, and aging, J. Coll. Interf. Sci., 145, 127-139, doi:10.1016/0021-9797(91)90106-I, 1991.
Walling, D. E., Collins, A. L., and Stroud, R. W.: Tracing suspended sediment and particulate phosphorus sources in catchments, J. Hydrol., 350, 274-289, 2008.

Wassen, M. J., Venterink, H. O., Lapshina, E. D., and Tanneberger, F.: Endangered plants persist under phosphorus limitation, Nature, 437, 547-550, 2005.

Withers, P. J. A. and Haygarth, P. M.: Agriculture, phosphorus and eutrophication: a European perspective, Soil Use Manage., 23, 1-4, doi:10.1111/j.1475-2743.2007.00116.x, 2007.

Wolthoorn, A., Temminghoff, E. J. M., Weng, L., and van Riemsdijk, W. H.: Colloid formation in groundwater: effect of phosphate, manganese, silicate and dissolved organic matter on the dynamic heterogeneous oxidation of ferrous iron, Appl. Geochem., 19, 611-622, doi:10.1016/j.apgeochem.2003.08.003, 2004. 